\title{
The Reception of Memes as Political Information in the Media
}

\author{
Hedi Pudjo Santosa ${ }^{* 1}$, Sri Budi Lestari ${ }^{1}$, Primada Qurrota Ayun ${ }^{1}$ \\ ${ }^{1}$ Department of Communication, Universitas Diponegoro, Central Java, Indonesia
}

\begin{abstract}
Lately memes have been using as viral marketing for products in advertising or satire in political campaigns in Indonesia. In 2013 Richard Dawkins, the author of The Selfish Gene (1976), characterized that memes on the internet as a human creativity. The pictures in the meme are tailored to the user's feelings and become the feeling of society. Meme cannot be said to be the ideal journalistic formula because most of them do not use the $5 \mathrm{~W}+1 \mathrm{H}$ journalism rule. Ironically though meme is not information that contains accuracy, relevance, and completeness of journalism, but at the same time it is in great demand even highly trusted, as they are easily accepted as information. While information that does not contain accuracy, often called hoax news. In Indonesia meme experiencing a surge in volume during the last 2014 presidential election; there are so many memes about Jokowi and Prabowo circulating on the Internet at the time, and later also many outstanding memes that contain the image in the form of satire, silly and even funny. Meme phenomenon related closely with the ease of dissemination of information through the media, especially online media. Bauckhage (2011: 42), meme usually develops through comments, imitations, parodies, or even media coverage. Meanwhile, according to Shifman (2013: 362), meme phrases are generally applied to describe propaganda. In Indonesia, meme is dominated by political news and satire especially during the 2014 presidential election.
\end{abstract}

Keywords: Reception, Meme, Political information, New Media

\section{Introduction}

The fast development of technology in this era has made information easier to be spread and accessed. Morissan explained that in regard of freedom of media when delivering news there has to be information which represents various sides and responds to numerous interests and need [1].

However, there's a shift in journalistic work nowadays that in delivering information the fundamental formula of $5 w+1 \mathrm{~h}$ often ignored. Every information product of media shall prioritize accuracy and relevancy of the news. Accuracy is the conformity of the delivered news and the sources of the news. Aside of both aspects completeness of the news is also a crucial factor of information [2].

In the last couple of years there's a new trend of information through weird and funny pictures with sarcastic meaning used to express someone's feelings in cyber world. Some of Indonesian netizens identify this information through pictures as meme (read: meem).

A meme usually circulates in internet through one's social media to another and it can be really popular because aside of way of joking, it also can be used as strategy by a professional public relations marketing. Not only that because lately meme can also be used as a means of political campaign for viral marketing both for product commercial and as a satire in political campaign.

\footnotetext{
*Corresponding author: hedipudjos@gmail.com
}

In 2013, Richard Dawkins, the author of The Selfish Gene (1976), characterized internet meme as human creativity and because of that, the pictures that used reflect the feeling of the users. It's also because of the same reason why meme cannot be included as the ideal works of journalism because it doesn't contain proper format. Ironically, despite the absence of accuracy, relevancy and competency of its elements, it attracts huge interest from the audience as reliable source due to its understandable nature. However, information without accuracy could be pointed as hoax. As quoted from the statement of Masyarakat Anti Hoax Indonesia (Indonesia Anti Hoax Community) chairman in a press conference in celebrating "Masyarakat Anti Fitnah Yojomase" on January 14th 2017:

“...(a lot of) people are divided because of (believing) in hoax news and it can accelerate into physical violence. Hoax within information or news are going rampant as one of the effects of mass development in cyber technology. Almost everyone can access any information they want from their smartphones. Afterwards, it was also mentioned that approximately 130 million of Indonesian people accessed internet through their mobile devices, but in contrast the cultural literacy is the second lowest in the world. Hence, the 
culture of sharing (an article) without being accompanied by the culture of reading" [2].

In Indonesia, there was a surge of volume for meme during the 2014 presidential election; so many memes about Jokowi and Prabowo circulating on the Internet at the time, and continued by a lot of outstanding memes which contain satire, silly and even funny images. The ease in receiving, processing, and producing information has impacted the high number of inaccurate, irrelevant, and incomplete sources. This phenomenon is closely related to the ease of disseminating information through the media, especially online. According to Bauckhage, memes are usually developed through comments, imitations, parodies, or even media coverage [3]. While according to Shifman [4], meme phrases are generally applied to describe propaganda on contents such as jokes, rumors, videos, or sites from one person to another via the internet.

Meme is a concept, idea, thought, or another work used on the internet as one of visual communication. It is a new thing and became popular in 2008 when a Hong Kong University student named Ray Chan created a site to share humorous interesting content in the form of videos, photos, and text. In a short time, Chan's site was successfully visited by 70 million people every month. The site is known as $9 \mathrm{Gag}$. This is the beginning where memes spread globally in the world, included Indonesia.

According to Boyd, networking community has four infrastructures that are very conducive to the meme formation: 1. Replicability: digital objects that are very easy to reproduce, easy to use, and penetrate economic and cultural boundaries. 2. Searchability: popular digital objects are easily found through search engines. 3 . Persistence: although digital objects cannot survive for analog objects, but they can be transferred and stored easily, an interaction will last much longer. 4. Invisible audience [5].

The meme phenomenon becomes an interesting thing to study in Indonesia because media accessibility makes people easily disseminate information in the form of memes to others without confirming whether the information contained in the meme is true (accurate) and in line with the journalism rules.

The ease in accessing and spreading information has made people believe anything they received without filtering. A meme is one form of information which often derived from an unclear source and without accuracy, but attracts a lot of interest and in return make people spread that information through their social media either consciously or unconsciously. It will become a problem when people one hundred percent trust this information. Besides, people have various way to accept information because of difference in way of thinking and personal experience.

Moreover, the easy access of receiving the meme as form of information leads to another issue happened lately in Indonesia about spreading information of national disaster that is related to the upcoming national election 2019.

\section{Methodology}

The paradigm that used in this research is constructivism. Constructivist considers reality as a form of mental construction, which is socially and experimentally based, characterized locally and specifically, in which the form and content depends on the human or group of individuals who construct it.

Within this paradigm we believe that the human mind is an active aspect in constructing knowledge. In other words, human neither find nor gain knowledge, but they form and compile it. We create concepts, models, and schemes to explain experiences and continually test and modify these constructions based on new experiences [6]. This paradigm is characterized by a strong attention to the lives of individuals. Its purpose is to understand the world subjectively based on human experience and to understand how social reality occurs at a certain time and place.

\section{Discussion}

Meme is a concept, idea, thought, or another work of art that is used in internet as visual communication tool. Meme can be in the forms of replicability; s digital object which is easy to reproduce and use which transcends economic and cultural barriers. In the 2014 presidential election, the dominant memes were about Jokowi and Prabowo who were rivals in the election. An informant said that some of the memes about them were considered as harassment and meme about Jokowi as a puppet president was one of them. And the meme about Jokowi as "antek aseng" (foreign henchmen) also was considered as disrespectful because there was no further information about it. Meme with negative content was dominant that time. In the Jakarta governor election, there were many memes which were made with intention to enliven the election. In fact, there was specific team which has responsibility to disseminate the memes to people. Each candidate or institution has specific team to create meme

Secondly, meme can be in the forms of searchability; a digital object which is easy to find and becomes popular in search engines. The reporters are quite selective to take meme as news resource in the media. Every reporter has their own standard, if they think that a meme has plausible social value, they will disseminate the meme. The intention of the dissemination is to make people understand a phenomenon in pleasant way.

Third, meme can be in the forms of persistence. Even though digital object does not exist as long as analog object, but it's easier to spread and be saved hence an internet interaction will be more sustainable. The correlation between meme and media. There is a synergy between meme and media because occasionally its resources comes from media and vice versa. For example, Kaesang with his "ndeso" and "kecebong" phrases. This meme became news resource for media

Lastly, meme can be as invisible audience. Digital object created by certain people in purpose to spread the knowledge to anyone in the internet. Meme is a satire 
which exists in a picture or a text about topic of discussions in a society. It could emerge in many forms, such as picture with satire elements, jokes, or amusing contents which have social control. Meme also could be formed in actual phenomenon which is occurred in society.

There are three hypothesis positions of meme readers based on Marris and Tornham's Reception Concept. First, dominant or hegemonic reading. The reader is in line with the program codes and fully accepts the meaning it is delivered and wanted by the meme maker. In the governor election of Jakarta, there were many memes which were made with intention to enliven the election. In fact, there was specific team which has responsibility to disseminate the memes to people. Each candidate or institution has specific team to create memes

Second, negotiated reading. The reader, in certain things, is agree with the program codes and fundamentally accepts the meaning it is delivered by the maker but they modify it so that it will reflect their personal interest. The reporters are quite selective to take meme as news resource in the media. They have their own standards. If they think that a meme has plausible social value, they will disseminate the meme. The intention of the dissemination is to make people understand a phenomenon in pleasant way.

Last, the oppositional (counter hegemonic) reading, where the reader is against the program codes. In the presidential election 2014, the dominant memes were about Jokowi and Prabowo who were rivals in the election. An informant said that some memes about them were considered as harassment and meme about Jokowi as a puppet president was one of them. And the meme about Jokowi as "antek aseng" (foreign henchmen) also was considered as disrespectful because there was no further information about it. Meme with negative content was dominant in the presidential election 2014.

The never-ending trend of using meme until today becomes the opportunity for agenda setting of upcoming national election campaign. The natural disasters happened lately throughout 2018 end up as environmental stir issue for opposing status quo ongoing government administration to show how shabby their administration in managing the environment and natural disaster mitigation.

\section{Conclusion}

Memes as political way usually develops through comments, imitations, parodies, or even media coverage. Its phrases are generally applied to describe propaganda. Meme phenomenon in Indonesia is closely with the ease of dissemination of information through the media, especially online media. There was a surge of volume for meme during the 2014 presidential elections about Jokowi and Prabowo circulating on the Internet at the time, and later on there are also a lot of outstanding memes which contain satire, silly and even funny images. The meme is dominated by political news and satire especially during the 2014 presidential election.

\section{References}

1. Morissan, et. al., "Teori Komunikasi Massa”, Ghalia Indonesia, Bogor (2010)

2. Liputan6.com, "Penyebab Orang Indonesia Rentan Percaya Hoaz di Medsos Terkuak", retrieved from https://liputan6.com (2017).

3. C. Bauckhage, "Insight into Internet Memes". Proceedings of the Fifth International AAAI Conference on Weblogs and Social Media pp 42-49 (2011)

4. L. Shifman, "Memes in a Digital World: Reconciling with a Conceptual Troublemaker". Journal of Computer-Mediated Communication pp 362-377 (2013)

5. D. Boyd, "Why youth (heart) social network sites: The role of networked publics in teenage social lifee, D. Buckingham (ed.), MacArthur Foundation Series on Digital Learning - Youth, Identity, and Digital Media, MIT Press, Cambridge (2007)

6. N. K. Denzin and Y. S. Lincoln, "Handbook of Qualitative Research", Pustaka Pelajar, Yogyakarta (2009) 